\title{
Difference in Marx: the lumpenproletariat and the proletarian unnamable
}

\author{
Nicholas Thoburn
}

\begin{abstract}
This article considers the place of difference in Marx's politics through an exploration of his categories of the lumpenproletariat and the proletariat. Far from a simple set of class subjects or empirical peoples, these two categories are argued to describe particular modes of political composition. Despite the frisson of difference and excess which is usually associated with Marx's lumpenproletariat, it is argued to describe a mode of composition - and, in relation to anarchism, a politics - oriented not towards difference and becoming, but towards present identity. The proletariat, on the other hand, is shown to be not a People, historical Subject or identity, but a 'minor' political mode of composition immanent to the manifolds of capitalism, and premised on the condition that, as Deleuze puts it, 'the people are missing'.
\end{abstract}

Keywords: proletariat; lumpenproletariat; Marx; minor politics; Deleuze; anarchism.

When the proletariat proclaims the dissolution of the existing world order, it is only declaring the secret of its own existence, for it is the actual dissolution of that order.

(Marx 1975: 256)

The power of minority, of particularity, finds its figure or its universal consciousness in the proletariat.

(Deleuze and Guattari 1988: 472)

When Marx writes of the proletariat in The Eighteenth Brumaire of Louis Bonaparte, he presents less a neat dialectical trajectory of an authentic historical subject, than a process of complication, interrogation and iteration. 'Proletarian

Nicholas Thoburn, Department of Sociology, Goldsmiths College, University of London, New Cross, LondonSE146NW.E-mail:sop01nt@gold.ac.uk 
revolutions', he writes, 'such as those of the nineteenth century, constantly engage in self-criticism, and in repeated interruptions of their own course. They return to what has apparently already been accomplished in order to begin the task again.' To mark that this return is not a repetition of the same, but an always situated process which seeks to draw in the new, he tells us that the proletarian social revolution 'can only create its poetry from the future' (Marx 1973a: 150, 149). This article takes up Marx's injunction and returns to the question of the proletariat. It returns not to reproduce that way of thinking Donzelot (1979: 73) describes as a compulsory reverence for a certain set of revered political figures, but from a contemporary concern to elucidate the function and place of 'difference' in Marx's proletarian standpoint. It seeks to show that at the core of Marx's formulation of the proletariat - and despite the work of orthodox Marxism, and those who would draw too neat an historical break between modernist and postmodernist political thought - lies a politics which at once highlights the problems of identity and compels a practice of invention and becoming. This is an important move if Marx is to maintain contemporary pertinence not just as an analyst of the dynamics of capital - as the bad conscience-fuelled praise of 1990s business journals would have it (cf. Wheen 1999: 5) - but also as a thinker of its overcoming. For, if there is a common concern in contemporary theory after ' 68 , the poststructuralist intervention and the turn to the study of minority politics - it is that politics resides in processes of difference, invention and complexity against the strictures of identity.

Talking of the proletariat in terms of difference might seem a little strange, since it is in many ways the great unitary teleological subject against which much post-'68 work on difference emerged. From Frantz Fanon and the Black Panther Party, through European counter-cultural groups such as the British Heatmave and the Dutch Provos (both of whom had some relation to the Situationist International), 1970s deviancy theory, to recent poststructuralist exploration of a politics beyond identity, it is towards the lumpenproletariat that interest in complexity and difference in Marx has tended to be oriented. Here the lumpenproletariat is variously seen as the declassé break with an incorporated working class, the class of the refusal of work or the site of an unassimilable heterogeneity that breaks Marx's otherwise modernist meta-narrative. It is indeed in the lumpenproletariat that difference and anomaly as a property of peoples is most apparently foregrounded by Marx, such that, when placed in contrast with the conventional image of the Marxian proletariat, it appears to be an attractive category for those seeking to develop a politics of difference. That Marx's critique of the lumpenproletariat is frequently framed in rather moral terms seems only to add to its appeal, as if even for Marxists a lumpenproletarian politics offers the possibility of overcoming the last remnants of bourgeois morality in his worldview. This article argues, however, that this is a problematic interpretation. Through a consideration of the way Marx elaborates the contours of the proletariat in a kind of fort/da game with the lumpenproletariat, it seeks to show, against conventional interpretation, that they describe not social groups, but modes of political composition. Despite the frisson of excess that circulates around the 
lumpenproletariat such that it looks like a category of difference, the article argues that the lumpenproletariat is actually a mode of composition which is oriented towards the maintenance of identity, and that it is in the proletariat where difference emerges, as a mode of complication, invention and becoming immanent to the social flows and relations of the capitalist socius.

To make this case, the article seeks to show that Marx's proletariat resonates with the kind of difference, becoming and creation that Deleuze and Guattari (1986, 1988), following Kafka, elaborate as a 'minor politics'. There are three interrelated aspects of minor politics that are useful for considering Marx's proletariat: 1) a politics against identity, 2) a consequent emphasis on social relations and 3) an intensive mode of engagement. 1) Deleuze and Guattari's minor politics is a direct challenge to political models founded on the representation of a subject or an identity, whether in the form of a 'People' or a self-declared marginal. Against these molar models, which are premised on the fetishization of an already present identity, minor politics operate in the 'cramped spaces' and 'impossible' positions of 'small peoples' and 'minorities' who lack or refuse coherent identity - those who, constrained by a wealth of determining social relations, exist under, and in a sense affirm, the condition that 'the people are missing' (Deleuze and Guattari 1986: 16-17; Deleuze 1989: 216). 2) But minor politics is not a resigned turn to the local or particular as such. Rather, it is a politics oriented towards social relations and their possibilities for becoming beyond identity. For, in cramped space - without self-secure delineated identity and autonomous concerns - politics ceases to be a self-referential process of selfactualization, and becomes a process of engagement with the social relations which traverse minorities and determine their movements; a necessary move if anything is to be actively lived. 3) The milieu of such an engagement is never able to settle, or soar into the self-actualizing grandeur of a People. Instead, it is an 'incessant bustle' charged with vitality, with polemic, and with a continuous process of interrogation, intrigue and invention as minorities engage with these social relations and seek to turn them away from their molar effects, towards, as Deleuze and Guattari (1983: 382) enigmatically suggest, a 'becoming everybody/everything' in the ever-renewed calling forth of a 'new earth'. Linking this project with Marx, Deleuze and Guattari (1988: 472) suggest - in a passage that has received scant critical attention - that the universal figure of minor politics is the proletariat.

In its exploration of the proletariat as a minor political figure, this article is in two main parts. The first part explores Marx's elaboration of the lumpenproletariat. It starts with a brief summary of critical work on the category, and then shows how the lumpenproletariat emerges across Marx's works - in terms of its relation to history, production and political action. This part ends by showing how Marx's critique of the lumpenproletariat as a non-revolutionary (non-)class is related to his critique of anarchism. Despite looking like difference, the lumpenproletariat is shown to be a mode of practice oriented towards the bolstering of identity cut-off from social relations. The second part of the article turns to the proletariat. It argues that the proletariat is less a group of people, 
than a mode of practice that is premised on the minor condition that the people are missing. It exists in Marx's texts as a non-identitarian mode of composition - a minor figure or 'unnamable' - immanent to the mutational social relations of capital. ${ }^{1}$ This part explores the absence of the proletariat from Capital, Marx's intensive or minor mode of engagement, and the proletariat's relation to the manifold social relations of capital and the critique of work. While the first part of the article follows the empirical detail of Marx's critique of the lumpenproletariat (and, in this, shows some of Marx's minor or proletarian mode of engagement with his milieu), the second part works at a more conceptual level, and is relatively concise. Though there is some discussion of Marx's actual practice, the point here is to map the general framework, or mode of composition, of Marx's proletarian unnamable, a practical elaboration of which is necessarily left to the multiplicity of specific, and ever-new, socio-historical situations within which the proletariat finds itself.

\section{Critical work on Marx's lumpenproletariat}

In the relatively small amount of critical work devoted to explication of Marx's lumpenproletariat it is something of a truism that Marx leaves the category rather undeveloped. Yet, while one may be tempted to interpret this conceptual underdevelopment as a sign of the relative insignificance of the category as compared to the serious business of Marxian political economy (one might hence point out that it is in Marx's historical and journalistic essays, rather than, say, Capital, where the category figures most prominently), the lumpenproletariat actually has a pivotal place in Marx's understanding of radical class formation. The critical work on Marx's category falls roughly into two perspectives. First, in the 1970s it tends towards a mapping and clarification of the category in the process of delineating a clear constituency of the lumpenproletariat and proletariat, and, second, from the late 1970 s, the lumpenproletariat returns as a site of difference in poststructuralist attempts to deconstruct Marx and open up difference in his texts. ${ }^{2}$ I shall briefly consider these perspectives.

The classic work by Draper begins by lamenting the tangled 'misunderstandings, misinterpretations and even mistranslations' (1972: 2285) that have accompanied the category of the lumpenproletariat. In an admirable work of explication, Draper develops what he sees as the specific historical, political and economic meanings of the category, suggesting that, though underdeveloped, there is nevertheless something quite distinct about the lumpenproletariat as, most essentially, those peoples that 'are being exuded, extruded, excreted from the class structure and onto the scrapheap' (ibid.: 2308). Hirst (1972) undertakes a similar task of clarification, though this time in favour of laying bare the facts of Marxian class analysis in an analytic arbitration that replicates Marx's contempt, but now specifically directed at radical deviancy theorists who would 
seek to include criminal practice and marginals within the community of the workers' movement. Hirst suggests that the condemnation of the lumpenproletariat should not be dismissed merely as bourgeois moralism on the part of Marx and Engels; on the contrary, it is the result of a sophisticated materialist understanding of the reactionary nature of the marginal and criminal classes.

The conceptual contours of the lumpenproletariat are, however, not so easily identifiable. Marx's account of the lumpenproletariat cannot be easily read as a simple analytic cleansing of the dangerous classes for the simple fact that he does not succeed in producing a clear constituency - successfully excised or not. This nebulous non-class takes multiple guises (from financial aristocracy and Louis Bonaparte to secret society conspirators, criminals, service workers and indeed 'pen pushers'), and is placed in varying historical trajectories (sometimes as a last manifestation of pre-industrial forms, sometimes as a strictly modern manifestation of industrial cities). As such, it appears to pop up everywhere rather than exist as a neat and distinct social group. Such confusion has led some more recent theorists, influenced by psychoanalysis and poststructuralism, to posit the lumpenproletariat not as a social group, but as the irruption of heterogeneity in Marx's conceptual system. In a fascination/repulsion account of lumpen decrepit excess, Andrew Parker suggests that in Marx's lumpenproletariat we see the '(de)structuring effects of eroticism' (1993: 23) and a repressed 'economy of anal pleasures' (ibid.: 34) between Marx and Engels. And Peter Stallybrass (1990) uses psychoanalytic frameworks to argue that Marx composes the purity of the dialectic through the spectacle of lumpen heterogeneity. In this, he suggests, the lumpenproletariat may be the space of 'the political' as it escapes from determined class composition (in an argument which would seem to make Laclau and Mouffe, with their 'autonomy of the political', cultivators of a contemporary lumpen swamp flower). But the classic work here is Jeffrey Mehlman's (1977) Revolution and Repetition. Mehlman argues that, on Marx's contact with the lumpenproletariat in The Eighteenth Brumaire, 'a certain proliferating energy is ... released' (1977: 13) that disrupts all dialectical identities with an unassimilable heterogeneity:

Where the higher was inevitably to be overthrown by the lower - the bourgeoisie by the proletariat - those two poles remain constant and are mutually impoverished by a strange irruption of something lower than the low . . . at the top. For Bonaparte seems to short-circuit both dialectic and class struggle in gathering in his service the 'scum (Ausmurf), offal (Abfall), refuse (Abhub) of all classes', the lumpen-proletariat ... . [A] specular - or reversible - relation is exceeded by a heterogeneous, negatively charged instance whose situation is one of deviation or displacement in relation to one of the poles of the initial opposition.

(Mehlman 1977: 12-13)

Mehlman's rather Derridean conclusions that, despite himself, Marx cannot help affirming the heterogeneity of the lumpenproletariat and his notion that it is a specifically literary Marx where difference emerges are problematic (not 
least, as is also the case with Derrida (1994), because the argument fails to seriously address the materialist core of Marx's thesis). However, Mehlman's concern not to elaborate the identity of the lumpenproletariat but to consider its relation to heterogeneity across Marx's system as a whole is one I have some affinity with. Where this article differs is that it presents heterogeneity not as a lumpen disruption of a neat dialectical schema of the bourgeoisie and proletariat as two distinct classes, but as a property of the category of the proletariat. To make this case we need to turn to Marx's work.

\section{The proletariat as bourgeois knave class}

Marx's category of the lumpenproletariat does not emerge as a simple addition to an already fully developed historical materialist lexicon populated by clearly elaborated class agents. Indeed, in many ways the categories of the proletariat and lumpenproletariat develop integrally. In the 1840s, as Bestor (1948) has shown, the vocabulary of the nascent socialist, communist and anarchist movements was in a state of formation, and many different terms were coined in rapid succession in a veritable neological feast. ${ }^{3}$ It is striking, for example, that, when in 1848 Marx and Engels set forth the communist programme, the word 'communist' was only eight years old (emerging from the secret societies under the July Monarchy) and was still very much undetermined in its content. More pertinent to my argument, while the term proletarius was used to describe the lowest class of ancient Roman community, the European variants of the words 'proletariat' and 'proletarian' were emerging into a modern definition as 'free wage worker' only in the late 1830 s and 1840 s with the developing workers' movement (cf. Bestor 1948: 275; Draper 1972: 2286; Linebaugh 1991: 121-2). ${ }^{4}$ Until then, it had decidedly derogatory connotations.

Originally designating those who had no value other than that they produced offspring, then vanishing from use in the second Christian century (Briefs 1937), from the fourteenth century up until Marx's era, 'proletarian' was a derogatory term akin to 'rabble' and 'knave'. In Samuel Johnson's 1755 Dictionary (cited in Linebaugh 1991: 122) for example, the proletariat was described as 'mean, wretched, vile, or vulgar', and later, in the 1838 Histoire des classes ouvrières et des classes bourgeoises, Granier de Cassagnac described it as a sub-human class formed of a cross between robbers and prostitutes (Benjamin 1983: 22). Haussmann characterized the proletariat as a 'mob of nomads', and in 1850 Thiers spoke of 'this heterogeneous mob, this mob of vagabonds with no avowed family and no domicile, a mob of persons so mobile that they can nowhere be pinned down' (cited in Chevalier 1973: 365, 364).

\section{The lumpenproletariat as Marx's knave class}

At a basic level, the lumpenproletariat is Marx's mechanism for freeing up his concept of the proletariat from the bourgeois image of a seething rabble; he 
transfers all the old content into the new category of the lumpenproletariat. In a sense, then, Stallybrass and White (1986) are right to situate Marx's excessive account of the lumpenproletariat in the general economy of bourgeois obsession with the 'other' of the poor (as most notably exemplified by Henry Mayhew). However, inasmuch as Marx is concerned with the problematic of revolutionary class formation (rather than the formation of bourgeois identity through moral condemnation and eroticization of the mass), there is a lot more going on in this transfer. As such, we would be wrong to stop here.

Marx and Engels are credited by the OED as the first to coin the composite 'lumpenproletariat'. It first appears in The German Ideology where it is used to describe both the ancient Roman plebeians (as 'midway between freemen and slaves, never becoming more than a proletarian rabble [lumpenproletariat in German]') and Max Stirner's self-professed radical constituency of the Lumpen or ragamuffin (Marx and Engels 1976: 84, 202). The prefix 'lumpen' is not to be taken as synonymous with poverty. Though Marx and Engels do often use the term to describe the very poor, Draper (1972) suggests that the principle root is not Lumpen meaning 'rag' and 'tatter', but Lump (pl. Lumpen, Lumpe) meaning 'knave'. This definition of the lumpenproletariat as a class of depraved knaves is no clearer than in Marx's famously excessive description of Louis Bonaparte and his December 10 Society:

On the pretext of founding a benevolent society, the lumpenproletariat of Paris had been organized into secret sections.... Decayed roués with dubious means of subsistence and of dubious origin, ruined and adventurous offshoots of the bourgeoisie, rubbed shoulders with vagabonds, discharged soldiers, discharged jailbirds, escaped galley slaves, swindlers, mountebanks, lazzaroni, pickpockets, tricksters, gamblers, maquereaux, brothel-keepers, porters, literati, organ-grinders, ragpickers, knife grinders, tinkers, beggars - in short, the whole of the nebulous, disintegrated mass, scattered hither and thither, which the French call la boheme; from this kindred element Bonaparte formed the core of the December 10 Society. A 'benevolent society' - in so far as, like Bonaparte, all its members felt the need to benefit themselves at the expense of the labouring nation. This Bonaparte who constitutes himself chief of the lumpenproletariat, who here alone rediscovers in mass form the interests which he personally pursues, who recognises in the scum, offal and refuse of all classes the only class upon which he can base himself unconditionally.

(Marx 1978: 73)

The constituency of this knave class is complex indeed. And, as if to match this complexity conceptually, the word lumpenproletariat is itself unstable in Marx's and Engels' work. In the many translations, including those by Engels, the German 'lumpenproletariat' is variously rendered as 'social scum', 'dangerous classes', 'mob', 'swell-mob', 'ragamuffin', 'ragged-proletariat'. And Marx and Engels often use other terms in place of 'lumpenproletariat' (particularly 'la bohème' and 'lazzaroni' but also German versions of the above English translations), all of which conjure different specific meanings as they are used to 
characterize an apparent group of people. This is indicative of the way Marx seems to need to resort to empirical description of the lumpen (albeit in a rather theatrical fashion) rather than present a neat conceptual class definition (such as with wage labourers: those who have nothing to sell but their labour). He sees the lumpenproletariat as, by definition, a nebulous, disintegrated group without stable collective determination - they are a 'non-class', a 'people without a definite trace' (Marx 1973c: 52-3).

It thus seems as if Mehlman (1977) was right. The content and contours of the lumpenproletariat appear to proliferate beyond all reason, as a nebulous mass in an indeterminate category. We would be wrong, however, to interpret this nebulous non-class as a force of difference. Across all its various manifestations there is, in fact, a key defining characteristic: it is a mode of practice oriented towards the bolstering of identity cut-off from the flows and relations of the social. The lumpenproletariat is not itself an identity (a particular social group), but in each of the diverse sites of its emergence in Marx's texts, it is a tendency tomards the maintenance of identity. To make this case I will look at the ways the lumpenproletariat functions in relation to four themes: history, production, political action, and - drawing these themes together - anarchism.

\section{The lumpenproletariat and the backing up of history}

Marx's most detailed consideration of the lumpenproletariat emerges in his accounts of the 1848-52 revolutions in France (or, more precisely, the triumph of counter-revolution) in Class Struggles in France and The Eighteenth Brumaire. Indeed, in identifying the twenty-seven times that Marx and Engels use the term 'lumpenproletariat' and its direct cognates, Traugott (1980: 712) has shown that the bulk appear in this four-year period. The years of reaction that followed the wave of revolutions were not a good time for the emerging workers' movement, or for the predictive efficacy of Marx's historical method. Mehlman (1977: 24-5) thus suggests that The Eighteenth Brumaire reads as though 'Marx must have lived the history of France from 1848 to 1852 - the revolution careening backwards - as resembling nothing so much as a latrine backing up'. Despite a relatively developed capitalist social structure and the ease with which Louis-Philippe was deposed and the Second Republic established, France experienced not the emergence of proletarian power, but the return of reaction under the leadership of Louis Bonaparte. Thus, quite contrary to Engels' assertion that The Eighteenth Brumaire reflects Marx's discovery of 'the great law of the motion of history' (preface to Marx 1978: 7), it reads as Marx's attempt to explain an historical development that by his system is actually somewhat of an anomaly. In this explanation the lumpenproletariat has a central place.

Laying the foundation for Marx's explanation of this anomalous development, the opening pages of The Eighteenth Brumaire consider not the neat teleology of class struggle (as laid out, for example, in the Communist Manifesto, written just before the 1848 revolutions), but the complex nature of the relation 
between memory and forgetting in the passage of historical change. The discussion resonates less with the historical narratives of orthodox Marxism than with Nietzsche's account of reactive historical processes. In Foucault's (1977: 160) reading of Nietzsche, the European tendency to raid the historical 'storeroom of costumes' in a process of the 'substitution' of 'alternate identities' - the sword of the German hero in the Wagnerian era, the knight's armour in romanticism - may look like difference, play and masquerade (and, indeed, such a carnivalesque relation to history offers some hope for the genealogist), but it is actually a guise for the 'comic' repetition of the identity form: each historical costume is drawn upon not to 'unrealize' but to solidify present identity. Marx describes the French under Bonaparte in precisely these terms. At the moment of revolution, rather than interrogate, borrow, criticize and ultimately overcome their inherited conditions, costumes and identities - tending towards the proletarian overcoming of history which 'can only create its poetry from the future' (Marx 1973a: 150, 149) - the French were instead inclined to make a reactionary return to the identities of the past. History famously repeats itself as 'farce', in a repetition, as Deleuze (1994: 91-2) interprets Marx's passage, which falls short of accentuating difference. Instead of tragic metamorphosis we see comic involution:

An entire people, which had imagined that by means of a revolution it had imparted to itself an accelerated power of motion, suddenly finds itself set back into a defunct epoch and, in order that no doubt as to the relapse may be possible, the old dates arise again, the old chronology, the old names, the old edicts.

(Marx 1978: 12)

Though Marx argues that Bonaparte's class base is the smallholding peasant, it is ultimately the lumpenproletariat which is the sign of this farcical repetition. Marx presents the Bonapartist state as a great farcical ruse whereby the non-class of the lumpenproletariat, in the December 10 Society and the 'swamp flower' of the Mobile Guard, seems to transfix the revolutionary potential of history. The lumpenproletariat thus develops as a plethora of farcical identities, ruses and anomalies in a world turned upside down, where the bourgeoisie cried 'Only theft can still save property; perjury, religion; bastardy, the family; disorder, order!' (1973a: 245) As Parker (1993) has argued, Marx reads the period 1848-52 as quite literally a farcical piece of theatre where correct class roles are undermined as the people act through their confused simulacral roles as 'remplaçants' and 'substitutes' (Marx 1973a: 244). ${ }^{5}$ Thus, the description of Bonaparte and his 'society of disorder, prostitution and theft' (ibid.: 198), the 'drunken soldiery, which he has bought with liquor and sausages' (Marx 1978: 124) continues:

An old, cunning roué, he conceives of the historical life of nations and their state proceedings as comedy in the most vulgar sense, as a masquerade in which the grand costumes, words and postures merely serve as a cover for the most petty trickery.... For his landing in Boulogne he put some London 
flunkeys into French uniforms to represent the army. In his Society of 10 December he assembled ten thousand rogues, who were supposed to represent the people in the way that Snug the joiner represented the lion. . . . [T] serious clown [Bonaparte] . . no longer sees world history as a comedy but his comedy as world history.

(Marx 1973a: 197-8)

\section{The unproductive lumpenproletariat}

The basis for the lumpenproletariat's reactive relation to history lies in its relation (or lack thereof) to productive activity. This is, of course, the most important aspect of Marx's account, for it is their relative relations to production that distinguish the lumpenproletariat and the proletariat. I want to leave the discussion of productive relations until the second part of this article. Here I shall only mark Marx's and Engels' comments about the lumpenproletariat's relation to production.

Marx's and Engels' most vehement assaults are saved for those who seem to revel in surviving outside productive relations. This point is made implicitly in Marx's critique of the debauched pleasures of the lumpenproletarian drunkard, but it is also made explicitly. In an example highlighted by Draper (1972), Engels contemptuously describes a procession of the 'unemployed' (Engels' scarequotes) through Pall Mall (organized by H. M. Hyndman's Social Democratic Federation) as 'mostly of the kind who do not wish to mork - barrow-boys, idlers, police spies and rogues. ... [T] [Te lumpen proletariat Hyndman had taken for unemployed' (in Marx and Engels 1995: 407, 408, emphasis added). But this severing of relations to productive activity is a mark not just of the 'unemployed' poor. In his discussion of the July Monarchy (1830-48) in Class Struggles in France, Marx describes the financial aristocracy as lumpenproletarian. If the December 10 Society was an historical inversion where the social dregs of society had somehow swindled their way to the top, here we find the social élite performing as the social dregs, where financial speculation replaces the proper class role of engagement with productive industry:

The July monarchy was nothing more than a joint-stock company for the exploitation of France's national wealth. . . Commerce, industry, agriculture, shipping - the interests of the industrial bourgeoisie were inevitably in permanent peril and at a permanent disadvantage under this system. ... [T]he same prostitution, the same blatant swindling, the same mania for self-enrichment - not from production but by sleight-of-hand with other people's wealth - was to be found in all spheres of society, from the Court to the Café Borgne [disreputable bars and cafés]. The same unbridled assertion of unhealthy and viscous appetites broke forth, appetites which were in permanent conflict with the bourgeois law itself, and which were to be found particularly in the upper reaches of society, appetites in which the wealth created by financial gambles seeks its natural fulfilment, in which pleasure becomes crapuleux 
[debauched], in which money, filth and blood commingle. In the way it acquires wealth and enjoys it the financial aristocracy is nothing but the lumpenproletariat reborn at the pinnacle of bourgeois society.

(Marx 1973c: 38-9)

\section{Lumpenproletarian spontaneity}

A third manifestation of the lumpenproletariat is seen in the context of political activity, when Marx writes of its possible radical tendencies. The lumpenproletariat is not almays counter-revolutionary. Though, in his extremes, Engels supports the shooting of thieves at the start of revolutionary events, Marx's and Engels' sense of the relative capacity of the lumpenproletariat as a revolutionary force is ambivalent. The lumpenproletariat vacillates (in The Peasant War in Germany Engels suggests that each day of the revolution sees them change positions) and is prone to reaction, usually offering their services to the highest bidder. But they can also find themselves involved in revolution, as their lack of stability leaves them easily swept up into revolutionary fervour. Thus, even the lumpenproletarian 'swamp flower' of the Mobile Guard, in so far as it was 'thoroughly tractable', was 'capable of the greatest acts of heroism and the most exalted self-sacrifice' (as well as, of course, 'the lowest forms of banditry and the foulest corruption') (Marx 1973c: 52-3). Marx makes a similar case with regard to the secret society professional conspirators. ${ }^{6} \mathrm{He}$ argues that their 'precarious' means of subsistence, dependent on 'chance' in 'irregular lives', and their 'constant dangers' situate this group as part of la bohême with an inclination to insurrection:

the greater the insecurity, the more the conspirator hastens to seize the pleasures of the moment... The desperate recklessness which is exhibited in every insurrection in Paris is introduced precisely by these veteran professional conspirators, the hommes de coups de main [men of daring raids]. They are the ones who throw up and command the first barricades, who organise resistance, lead the looting of arms-shops. . . In a word, they are the officers of the insurrection.

(Marx and Engels 1978: 318)

But Marx criticizes the conspirators, though insurgent, for their extra-social spontaneity. As 'officers of the insurrection' (rather than the revolution) these conspirators mistake the adequate preparation of their conspiracy for the revolution, and thus they attempt

to launch a revolution on the spur of the moment, without the conditions for a revolution. ... They are like alchemists of the revolution. ... They leap at inventions which are supposed to work revolutionary miracles: incendiary bombs, destructive devices of magic effect, revolts which are expected to be all the more miraculous and astonishing in effect as their basis is less rational. 
In these three manifestations of lumpenproletarian practice (in relation to history - as comic repetition of past identities, production - as a self-separation from social productive activity, and politics - as a vacillating spontaneity) we see a category which is marked by its externality to capitalist social relations and its inability to engage with the potential becoming of history. The political importance of this account comes to the fore in the unfolding of the First International - the emerging split between Marxism and anarchism - in Marx's dispute with Michael Bakunin, the man Engels dubbed as 'the lumpen prince' (cited in Bovenkerk 1984: 25$)^{7}$

Though the conventional presentation of the split between Marx and Bakunin centres on a statism/anti-statism conflict over the 'dictatorship of the proletariat', a far more important distinction (for all else emerges from it) resides in their differences on the question of the revolutionary agent. ${ }^{8}$ Whereas Marx, as I consider below, sees the emergence of the revolutionary proletariat as immanent capitalist social relations, Bakunin considers workers' integration in capital as destructive of more primary revolutionary forces. For Bakunin, the revolutionary archetype is found in a peasant milieu (which is presented as having long-standing insurrectionary traditions, as well as a communist archetype in its current social form - the peasant commune), and among educated unemployed youth, assorted 'marginals' from all classes, brigands, robbers, the impoverished masses, and those on the margins of society who have escaped, been excluded from, or not yet subsumed in the discipline of emerging industrial work - in short, all those whom Marx sought to include in the category of the lumpenproletariat (cf. Pyziur 1968: ch. 5). Thus, as the people capable of uniting 'private peasant revolts into one general all-people's revolt', Bakunin focuses on

free Cossacks, our innumerable saintly and not so saintly tramps (brodiagi), pilgrims, members of 'beguny' sects, thieves, and brigands - this whole wide and numerous underground world which from time immemorial has protested against the state and statism.

(Bakunin n.d.: 19)

Such people, Bakunin (n.d.: 20) argues in a fashion not so different from Marx's account of lumpen 'spontaneity', are fired with a transhistorical instinctual rage, a 'native movement' of a 'turbulent ocean', and it is this revolutionary fervour, immanent to their identities, not class composition within capitalism, which elects them for their political role:

Marx speaks disdainfully, but quite unjustly of this Lumpenproletariat. For in them, and only in them, and not in the bourgeois strata of workers, are there crystallised the entire intelligence and power of the coming Social Revolution.

A popular insurrection, by its very nature, is instinctive, chaotic, and destructive, and always entails great personal sacrifice and an enormous loss 
of public and private property. The masses are always ready to sacrifice themselves; and this is what turns them into a brutal and savage horde, capable of performing heroic and apparently impossible exploits, and since they possess little or nothing, they are not demoralised by the responsibilities of property ownership . . . they develop a passion for destruction. This negative passion, it is true, is far from being sufficient to attain the heights of the revolutionary cause; but without it, revolution would be impossible. Revolution requires extensive and widespread destruction, a fecund and renovating destruction.

(Bakunin 1973: 334)

Though Bakunin's category of the lumpenproletariat may have a broader catchment than Marx's, ${ }^{9}$ it is clear that they both largely agree on its components as an identity removed from capitalist social relations. While for Marx the lumpenproletariat is a tendency - vis-à-vis history, production and political action - towards identity, for Bakunin the lumpenproletariat embodies in its present identity a kind of actually existing anarchism. ${ }^{10}$ The centrality of present identity to Bakunin's formulation is such that, when he does venture into theory, he places a premium on abstract humanist concepts like freedom and equality. ${ }^{11}$ Bakuninist anarchism - for all its emphasis on the marginalized, down-trodden and rebellious - is thus subject to the same critique Marx raised against Utopian Socialism, as that which posits a transcendent idea of a perfect social form and deploys historically decontextualized 'eternal truths' of 'Human Nature' and 'Man in General', rather than engage with the expansive 'fluid state' of material life in specific sociohistorical relations (Marx and Engels 1973: 69, 67; Marx 1976: 103). ${ }^{12}$ It is to a politics of these fluid relations that I now turn.

\section{II}

If Marx's lumpenproletariat as a category of identity emerges through the amassing of attributes and historical examples, the non-identity of the proletariat - what I will call the 'proletarian unnamable' - is formulated with a decided lack of empirical description and hardly any sense of its positive content. In carving off the lumpenproletariat, Marx leaves the proletariat in a rather anaemic, stripped-down state. We would be wrong, however, to interpret the apparent lack of positive description as a sign of the simplicity or weakness of the proletarian political figure. In fact, as I argue below, the stripped-down formulation of the proletariat is central to its political force. Despite the fact that the proletarian mode of composition has been translated - through orthodox Marxism and the Soviet model - into a delineated molar subject with a clear and welldetermined set of political practices and techniques, I want to argue that Marx's proletariat describes a mode of composition which calls forth processes of minor difference and creativity without or against determined subjectivity. To make this case, the following discussion explores the mode of composition of Marx's proletariat through the framework of minor politics laid out in the introduction. 
It considers the 'absence' of the proletariat from Capital, Marx's consequent intensive and incessant engagement with his milieu (aspects 1 and 3 of minor politics) and the place of manifold social relations and work (aspect 2).

\section{Capital's missing proletariat and Marx's minor engagement}

In seeking to elaborate the contours of the proletarian unnamable it is instructive to follow some of Balibar's (1994) argument in his essay 'In search of the proletariat' (cf. also the other (1988) version). ${ }^{13}$ Balibar begins his search by pointing to a central paradox in Capital, namely that the proletariat - the agent of Marx's politics, that which links the analysis of exploitation to revolution - is almost completely absent. It is absent from the consideration of the labour process, the process of exploitation and of wages, and emerges only in terms of its insecurity, instability and embodiment of an economically instituted violence, rather than, say, its positive force. Unlike Negri (1991), who sees this absence as a sign of the 'objectivist' nature of Capital (such that he chooses to map his more 'subjectivist' Marx beyond Marx through the Grundrisse), ${ }^{14}$ Balibar (1994: 149) suggests that it is central to what Althusser sees as Marx's opening of a 'new continent of thought', vis-à-vis not just liberal categories of economics and politics, but also the radical political current of which he is part. This opening is not manifest as a neat break with the presentation of a new subject because given the proletariat's essence as a self-abolishing overcoming of the 'existing world order' (Marx 1975: 256) - it is impossible for Marx to present a positive identity within the terms of the milieu and episteme he works within. Instead, Marx practises an intense and heated engagement with the terms of his milieu. As Balibar argues, the vacillations in Marx's more overtly politically engaged works between the oppositions of economics/politics, statism/anarchy, compulsion/freedom, hierarchy/equality arise not from an intellectual weakness or uncertainty, but because these are the essence of the conceptual and political milieu of Marx's time, within which he is constrained - the space being 'full', or to use Deleuze and Guattari's terms, 'cramped':

In fact, what these still allusive analyses demonstrate is that Marx's 'political' theory and action have no proper space in the ideological configuration of his time. For this configuration is itself a 'full' space, devoid of any gap in which a specifically Marxist discourse could have established itself alongside, or opposite, other discourses.

(Balibar 1994: 135)

Given this cramped condition, Balibar (1994: 134) argues, for example, that Marx is unable to write an 'Anti-Lassalle' or an 'Anti-Bakunin' (however much more timely than Anti-Dühring these would have been). Instead, he presents 'notes' on the Gotha Programme and various notes and critiques of Bakunin as interventions in the milieu of the workers' movement - a little of which I have shown in Marx's work on the lumpenproletariat. 
This is a mode of activity that resonates with Kafka's characterization of minor literature. In minor literature,

There is universal delight in the literary treatment of petty themes whose scope is not permitted to exceed the capacity of small enthusiasms and which are sustained by their polemical possibilities. Insults, intended as literature, roll back and forth. What in great literature goes on down below, constituting a not indispensable cellar of the structure, here takes place in the full light of day, what is there a matter of passing interest for a few, here absorbs everyone no less as a matter of life and death.

(Kafka 1972: 150)

It is, indeed, precisely in these interventions that Marx becomes most animated. A political event, an adversary, a war, an economic crisis sets him off and he produces yet another pamphlet, forms one more alliance, partakes in another heated polemic; that is, he takes up the particular event, the apparently 'petty theme', and intricately engages with it. This mode of engagement is amply evident in Engels' exasperated comment about Marx's journalism:

He is no journalist, and will never become one. He pores for a whole day over a leading article that would take someone else a couple of hours as though it concerned the handling of a deep philosophical problem. He changes and polishes and changes the change and owing to his unremitting thoroughness can never be ready on time.

(cited in Wheen 1999: 131-2)

In this incessant and intricate engagement, Marx does not limit himself to a particular and autonomous discipline, but draws on the wealth of fields that surround him, from political economy to literature (notably Shakespeare and Dickens) and even gossip columns (cf. Wheen 1999: 237), and employs diverse modes of argument, from technical elaboration, to literary flourish and polemic (Capital would not be the same without the scatological tones of its denunciations of the bourgeoisie). His work seems to take him over, becoming, perhaps, a 'matter of life and death': the pamphlets, sometimes arising from petty squabbles, multiply in length (The Holy Family grows from a twenty-page polemic to a 200-page work), and he invariably develops illnesses, boils, carbuncles at the point of writing.

This minor mode of engagement is not incidental to Marx's elaboration of the proletariat. In it we can see precisely that process of iteration, 'interruption' and 'self-criticism' that Marx's (1973a: 150) account of the proletarian mode of politics (cited at the start of this article) emphasizes. The ease of the bourgeois revolutions - as they 'storm from success to success' (Marx 1973a: 150) - can be explained by the way that their political concerns are nurtured by the social environment of capital. ${ }^{15}$ As Deleuze and Guattari (1986: 17) write of major literatures and politics, 'the social milieu serv[es] as a mere environment or a background' for the easy elaboration and facilitation of individual concerns. The proletarian movement, on the other hand, experiences the social environment as 
hostile, as something which cramps its possibility for expression. It is thus unable to express any autonomous concern, and is forced instead to intimately and constantly engage with these social relations. And it is precisely through this engagement - and the conceptual and practical invention that arises from it that the proletariat composes itself, unsettling these relations, and seeking to open them up to something new. Balibar (1994: 136) thus argues that in his interventions Marx enacts a 'twisting of the dominant discourse that, in a given conjuncture, make[s] its coherence vacillate.' It is here, in this act of twisting, disruption and complication that Balibar (1994: 136) finds the essence of the critical force of Marxism, as, rather than demarcate an identity within nineteenth-century political discourse - rather than posit a People - it compels a 'perpetual work of refutation, interpretation, and reformulation'. It is precisely because it is unnamed - or, demarcated and elaborated as an autonomous political subject - that the radical force of the proletariat, $v i s-\grave{a}$-vis the identities and dichotomies of nineteenth-century thought is maintained.

To be at once unnamed and to carry the force of disruption there must, nevertheless, be signs of the proletariat - something for this incessant mode of engagement to draw out. Balibar (1994: 127) thus places considerable importance on the few explicit references to the proletariat in Capital. First, Balibar suggests that the occasional use of the term is the 'bridge' that allows Marx to cite significant passages from his earlier work, and so embed the text's analysis of capital in the workers' movement - a move symbolically confirmed in the dedication to Wolff. Second, Balibar draws attention to the addition of two references to the proletariat in the second 1872 edition: Marx's suggestion in the postface that the 1848 revolutions caused the breakdown of classical economics through the irruption of its repressed political content, and his discussion of the role of the working class in abolishing the Combination Acts (cf. Marx 1976: 97-8, 903). Crucially, these additions show the first signs of the proletariat not in the form of an autonomous identity - something which might 'face' capital as an opposing subject - but as a movement immanent to capitalist relations.

\section{Manifold relations and the refusal of mork}

Moving away from Marx's own mode of engagement and the specific work of Capital, these signs of the proletariat can now be placed in the broader context of Marx's conceptual system as a whole. Marx famously ties the proletariat - as we saw, in contradistinction to the lumpenproletariat - to social productive capitalist 'work'. This is a work which produces more than mere subsistence, or 'surplus value' as value in excess of the equivalent; a work which, as Spivak (1996: 109) puts it, is 'super-adequate'. This emphasis on work leads Marx to say some rather outrageous things about the educational benefits of child labour, ${ }^{16}$ and the legacy of orthodox Marxism has done much - as it collapsed communism into a red wage slavery ${ }^{17}$ - to mould Marx as a celebrant of work. But, and this point is often obscured (no doubt with the help of some of Marx's 
texts themselves), this necessary relation to work in the production of the proletariat is not an affirmation of mork itself. Marx is developing a politics immanent to the sociohistorical composition of life - the social relations of the capitalist 'mode of production' - not to any transcendental categories or practices. It is the centrality of work to capitalism - both as a transformative and a constraining power - that necessitates this focus.

Marx's theory of capital is a theory of the composition of life as a complex and mutating social system - an 'organism' (Marx 1973b: 693) - that assembles not distinct entities - say, workers, machines and natural objects - but relations and forces across and within apparent entities. Social forces and relations, in a sense, are primary: it is the way a socius conjugates its forces and relations that determines the forms and identities that populate it. So, for example, Marx's 'theory of machines' is not a transhistorical definition of the properties and effects of the machine, but a situated analysis of the way the capitalist socius composes human and technical forces. Marx thus presents machine-intensive production - when the machine comes into its own in what he calls 'real subsumption' - as a vast 'automaton consisting of numerous mechanical and intellectual organs', where the 'automaton' is the capitalist socius as a whole (Marx 1973b: 692).

The crucial point about the capitalist socius is that, unlike all previous modes of production, which sought to conserve a set of relations and identities, it operates through constant change - 'Constant revolutionising of production, uninterrupted disturbance of all social conditions' - as it seeks to continuously maximize surplus value in a process of production for production's sake (Marx and Engels 1973: 36). Since work is the productive force of capital, the source of surplus value, it is the means by which the human being is incorporated in the supra-individual automaton of the capitalist socius. It is in work that identities are dissolved in manifold and expansive global relations, and it is precisely in these manifold relations - what, following Nietzsche (1968: \$1066), we might call the becoming of the world - that the proletariat finds its milieu of composition.

Marx makes the importance of this complexity and becoming to the formation of the proletariat clear, negatively, in the Eighteenth Brumaire when he describes the smallholding peasant class. The problem is that the peasant condition, however massive (they are 'the most numerous class'), is not one of manifold relations:

The small peasant proprietors form an immense mass, the members of which live in the same situation but do not enter into manifold relationships with each other. Their mode of operation isolates them instead of bringing them into mutual intercourse. ... [T] he smallholding, permits no division of labour in its cultivation, no application of science and therefore no diversity of development, variety of talent, or wealth of social relationships.

(Marx 1973a: 238, 239; emphasis added)

The peasant class, Marx (1973a: 239) tells us then, is composed of 'the simple addition of isomorphous magnitudes, much as potatoes in a sack form a sack of potatoes'. ${ }^{18}$ In contradistinction, the proletariat is composed of manifold social, 
natural and technical relations, as it exists in that system where 'All that is solid melts into air' and that covers 'the whole surface of the globe', 'establish[ing] connections everywhere' (Marx and Engels 1973: 37).

But, if work is the way that the human being is deterritorialized as it is incorporated in the expansive and mutating social organism, it is simultaneously the mechanism of the reterritorializing and recoding forces of capital. It is the mechanism, that is, whereby manifold relations are turned into the molar form of 'worker' (with the attendant formal equalities and freedoms, fetishisms, alienations and exploitations) so as to enable the extraction of surplus value, such that work is also the constraining and 'vampiric' mechanism of capitalism. ${ }^{19}$ The capitalist and the worker are not, then, pre-given identities which face each other as distinct and opposing subjects, but are functions of capital, born, or, as Deleuze and Guattari (1983: 144) put it, 'miraculated' out of its body. Capital, that is, is an 'organic system ... [which] creat[es] out of it[self] the organs which it . . lacks': 'The capitalist functions only as personified capital, capital as a person, just as the worker is no more than labour personified' (Marx 1973b: 278, 1976: 989).

While the proletariat is constituted in the transformative manifold of capitalist relations, it cannot, then, be identified with 'the workers' as an autonomous and present identity, for this would be to base politics on an identity formed by, and functional to, the exploitation of capital. ${ }^{20}$ Instead, the proletariat is the class of the overcoming of work and its identities: it is a process which seeks to actualize an 'absolute movement of becoming' mithin and beyond the manifold social, technical, and natural forces and relations and constraining identities created by the capitalist socius (Marx 1973b: 488). ${ }^{21}$ At the core of the proletarian mode of composition we thus see the strange return of a theme that was used as the basis for the critique of lumpenproletarian practice - the critique of work. The difference is that, here, the critique of work emerges not in an autonomous sphere outside manifold capitalist relations, but as a politics immanent to them immanent, that is, to the class of workers. ${ }^{22}$ In this formulation, as Gilles Dauvé (1997: 31) once put it, 'The proletariat is not the working class, ${ }^{23}$ rather the class of the critique of mork'. As one might guess from his critique of the lumpenproletariat, Marx rarely makes this point explicitly, but the essence of the proletariat is the abolition of work:

It is one of the greatest misunderstandings to talk of free, human, social work, or work without private property. 'Work' is essentially the unfree, inhuman, unsocial activity, determined by private property and creating private property. The abolition of private property becomes a reality only when it is understood as the abolition of 'work'.

(Marx, 'Ueber Friedrich List's Buch Das Nationale System der Politischen Oekonomie', cited in Zeromork 1975: back cover)

This 'critique of work' is, of course, a rather ambiguous political proposition. Marx declines to offer a coherent and timeless programme of the way that the proletarian mode of composition should unfold: he neither describes the 
outcome of the proletarian overcoming (famously balking at the idea of writing 'recipes ... for the cook-shops of the future' (Marx 1976: 99)) nor does he present a set of timeless proletarian practices (be they the formations of the Party, trade unions or workers' councils, to name some of the more prominent forms the workers' movement - and its degenerations - has taken). ${ }^{24}$ To do so would be to tie proletarian practice to a particular sociohistorical form of work, and as such would lead to an increasingly anachronistic political practice, and, ultimately, to the formation of a 'proletarian' identity around a set of sanctioned political forms and techniques (cf. Camatte 1995). In leaving the question of practice at the general level of work and its critique, Marx leaves the proletariat as something which must continually find its own forms, and invent its own techniques from the specific configuration of work - the axiomatizing, constraining, cramping and vampiric practices and identities which populate the socius - that the proletariat finds itself within at any one time. Marx leaves the proletariat, that is, as an 'unnamable': it is not determined or 'named' in form or content, but is, rather, a compulsion to an ever renewed and situated mode of composition in and against the manifolds of capital and its identities as it seeks to magnify the becoming of the word against identity, and so 'create its poetry from the future' (Marx 1973a: 149). If the first basis for the continual 'self-criticism', 'return' and 'interruption' of proletarian politics was that the people were missing, the second basis, then, is that the social relations that are its milieu of composition (in a general sense, 'work') are ever-changing.

It is in this context that we can understand Deleuze and Guattari's (1988: 472) proposition that the proletariat is the universal plane of minor politics. Once we follow Marx's injunction to base politics in a critique of capital and its mutations - which can be seen as precisely Deleuze and Guattari's $(1983,1988)$ project in Capitalism and Schizophrenia ${ }^{25}$ - we can enrich Marx's general sense of 'work' to include the wealth of relations, attributes, affects of which contemporary social production is composed. Immanent in these relations is a multiplicity of cramped 'minority' peoples - peoples with particular experiences, practices and ways of being composed by these relations. Deleuze and Guattari's alignment of the minor and the proletariat is not a suggestion that these minorities should somehow amass as groups to form a larger group of the proletariat. It is, rather, that the plane of the proletarian unnamable is at any one time populated by, or composed of, a multiplicity of cramped, complex, minor sites of engagement and processes of political invention. As minorities' intrigues, inventions, self-criticisms, polemics and creations problematize, and seek to deterritorialize the manifold social relations which traverse them, they actualize a proletarian mode of composition in capital. ${ }^{26}$ In practice, this is of course complex, difficult and uncertain work, and the tendency to fall back on identity, as orthodox Marxism well exemplifies, is always present. But, ironically - given the certainties of the orthodox Marxist narrative - it is perhaps one of Marx's greatest lessons that politics emerges not from the self-certainty of identity, but from cramped and impossible positions where the people are missing, and must remain so if the 'secret' (Marx 1975: 256) of the proletariat - the movement of its own abolition - is to be actualized. 


\section{Conclusion}

This article has considered the place of difference in Marx's politics through an exploration of his categories of the lumpenproletariat and the proletariat. I have argued that, far from a simple set of class subjects or empirical peoples, these two categories describe particular modes of political composition. Despite the literary excess and the proliferation of names, Marx's lumpenproletariat describes a mode of composition - and, in relation to anarchism, a politics oriented not towards difference and becoming, but towards identity. To use Deleuze and Guattari's terms, this is a 'molar' politics in that in relation to history (as a comic repetition of past identities), production (as a self-separation from social productive activity) and political action (as a vacillating spontaneity), the lumpenproletariat is a mode of practice which does not seek to engage with the manifold relations of the social towards its overcoming, but turns inward towards an affirmation of its own autonomous and present identity. From a contemporary perspective, Marx's lumpenproletariat, then, is most interesting not because it is the moment of variation from class interest, the site of heterology in Marx's texts, or because it indicates his true polymorphous desire, but because it highlights the problem of a politics at the level of molar identity as abstracted from expansive social relations, even as it looks like difference.

The proliferation of historical names and attributes of the lumpenproletariat was shown to be in contradistinction to the unnaming of the proletariat. Marx seems to play a fort/da game where at each moment - in relation to history, production and politics - the lumpenproletarian tendency is cut off from the proletarian position. This does not, however, shore up the identity of the proletariat, for in each case the proletariat is left strangely absent: it is stripped down, seems to have no autonomous content and is given hardly any empirical description. Instead, the continual severing of the lumpenproletarian position is part of the opening of the space of the proletariat as a mode of composition - what I have called the proletarian unnamable - that seeks to overcome identity. Far from a weakness of Marx's position, the 'absence' of the proletariat is fundamental to Marx's minor politics - a politics premised on the propulsive condition that the people are missing. For, given the impossibility of delineating an autonomous and fully present identity in the cramped terrain of the capitalist socius, proletarian politics is compelled to an incessant process of polemic, critique and intervention in social relations. (In this sense, Marx's critique of the lumpenproletariat - the discussion of which takes up much of the body of this article is an exemplar of his proletarian practice.) The points of focus of this proletarian engagement are the manifold social, technical and natural relations and cramping molar mechanisms of capitalist production - or 'work' - such that the proletariat is the class of the critique of work. As I have argued, in Marx's formulation the generality of 'work' and the 'critique of work' is necessarily maintained because the specific exploration and elaboration of these relations and practices is to be ever-renewed through the most contemporary engagement. The very stripped-down nature of Marx's formulation of the proletarian unnamable is 
thus functional to its emergence in a multiplicity of different ways throughout the manifold social plane of production as it is configured in any one time and place. ${ }^{27}$ The practical elaboration of the proletarian mode of composition its political techniques, styles, cultures, knowledges - in all its difficulty, uncertainty and complexity is, hence, another story; something which Marx (1973a: 149) leaves open as a politics which 'can only create its poetry from the future'.

\section{Acknowledgements}

I am very grateful to Nikolas Rose for his comments on an early version of this article, and to Martha Michailidou, Margot Butler, Ben Gidley, Stephen Cross and Runa Khalique for their insights following my first airing of these concerns at the Millennial Values, Future Ethics research seminar at Goldsmiths College. I am grateful also for the comments of the anonymous referees of this article.

\section{Notes}

1 I have used Beckett's (1979) term 'unnamable' because it is a useful means of characterizing the proletariat as an immanent potential which cannot be fixed or 'named' in any one time or space. Essentially, though, following Deleuze and Guattari's (1983: 20-1) use of the term, the unnamable corresponds to the minor.

2 A third area of debate - on the conjunction of 'race', policing, unemployment and politics - is more empirically grounded. See, for example, Cleaver (1970), Gilroy and Simm (1985) and Hall et al. (1978). Because this article is an interpretation of the way the lumpenproletariat works in Marx's texts, a consideration of this work is beyond its scope.

3 As one example, a partial list of the Parisian 'sectes communistes' in 1842 included égalitaires, fraternitaires, humanitaires, unitaires, communitaires or icariens, communistes, communionistes, communautistes and rationalistes (Louis Reybaud, Revue des Deux Mondes, cited in Bestor 1948: 291).

4 It seems as though Sismondi was the first to use the term in a modern sense in his 1837 Etudes sur l'économie politique, and it is not without importance that Marx (1978: 5) prefaces The Eighteenth Brumaire with a reference to his definition: 'People forget Sismondi's significant saying: The Roman proletariat lived at the expense of society, while modern society lives at the expense of the proletariat.'

5 Though Marx's argument does at times rest on a dichotomy between lumpen 'acting' and 'real' historical production, I would argue that the useful point to draw out is not that Marx has a problem with the theatrical use of historical costume per se - as Parker (1993) emphasizes - but, as is similarly the case for Nietzsche, with the use of historical costume towards the maintenance of identity (rather than towards its overcoming) (cf. Marx 1973a: 148).

6 Marx's efforts to drive the secret societies out of the First International (as a Masonic social form far from the mass open movement that Marx saw in the Chartists and sought to develop in a proletarian organization (cf. Nicolaevsky 1997)) owe much to his conflicts with the Bakuninists and the conspiratorial forms of revolutionary politics most clearly expressed by Nechayev (1989) in his Catechism of the Revolutionist. To cite one passage among many, Nechayev describes the correct ethics of the covert nihilist revolutionary thus: 
The revolutionary is a dedicated man. He has no interests of his own, no affairs, no feelings, no attachments, no belongings, not even a name. Everything in him is absorbed by a single exclusive interest, a single thought, a single passion - the revolution. ... All the tender and effeminate emotions of kinship, friendship, love, gratitude and even honor must be stifled. . . Night and day he must have one thought, one aim - merciless destruction.

(Nechayev 1989: 4-5)

Though the controversy as to the source of this catechism seems to have cleared Bakunin from its authorship (cf. Avrich 1987), the conspiratorial and élitist thinking of Bakuninist anarchism - where the revolution is declared as popular but is to be secretly driven by a handful of conspirators - is put as strongly by Bakunin as Nechayev. For example, Bakunin writes:

We are bitter foes of all official pomer, even if it were ultra-revolutionary power. We are enemies of all publicly acknowledged dictatorship. . . Rejecting any power, by what power or rather by what force shall we direct the people's revolution? An invisible force - recognised by no one, imposed by no one - through which the collective dictatorship of our organisation will be all the mightier. . . . But imagine, in the midst of this general anarchy, a secret organisation which has scattered its members in small groups over the whole territory ... an organisation which acts everywhere according to a common plan.... This is what I call the collective dictatorship of the secret organisation.

(Bakunin n.d.: 26-7)

7 The rationale behind the exclusion of Bakunin's Alliance of Social Democracy from the International is explained in some 120 pages (Marx and Engels 1988), but begins by stating that the danger of a broad banner workers' movement, as the International's explicit concern, was always in letting in déclassé (lumpen) elements.

8 The argument that Bakunin perceives in Marx the seeds of statism - that he, in a sense, predicts the Soviet Union - is not uninteresting, but it can be made only by ignoring the centrality of Bakuninist notions of organization and 'invisible dictatorship' to Leninist politics (cf. Blissett and Home n.d.).

9 Bakunin seems to practise what Marx and Engels (1988: 520) refer to as a 'law of anarchist assimilation', whereby a whole series of groups (from religious sects to students and brigands) are brought under the banner of a spontaneist 'anti-authoritarian' movement. Marx's critique is not just that the collective 'community' of these formations is often little more than a product of Bakunin's imagination, but that it is also a cynical deployment of a populist rhetoric that disguises a tapestry of secret societies and 'invisible dictatorship' (cf. Marx and Engels 1988).

10 This is not to suggest that Bakunin was not an advocate of revolutionary change, but simply that his change was to be the expression of the identity of his political agent.

11 In Revolutionary Catechism, for example, Bakunin writes: 'Replacing the cult of God by respect and love of humanity, we proclaim human reason as the only criterion of truth; human conscience as the basis of justice; individual and collective freedom as the only source of order in society' (1973: 76).

12 Debord (1983) presents one of the most concise and incisive Marxist critiques of utopian socialism and anarchism in these terms (albeit a critique which could apply to the humanist and Hegelian tendencies in the Situationist International itself (cf. Ansell Pearson 1997: 155-60; Debray 1995)). Having argued that Marx's 'science' is an understanding of forces and struggle rather than transcendent law (Debord 1983: §81), Debord writes:

The utopian currents of socialism, although themselves historically grounded in the critique of the existing social organization, can rightly be called utopian to the extent that they reject history - namely the real struggle taking place, as well as the passage of time beyond the immutable perfection of their picture of a happy society.

(Debord 1983: §83) 
Debord then continues to consider anarchism:

The anarchists have an ideal to realize... It is the ideology of pure liberty which equalizes everything and dismisses the very idea of historical evil. . . Anarchism has merely to repeat and to replay the same simple, total conclusion in every single struggle, because the first conclusion was from the beginning identified with the entire outcome of the movement... [ [I]t leaves the historical terrain by assuming that the adequate forms for th $[\mathrm{e}]$ passage to practice have already been found and will never change.

(Debord 1983: §92)

13 Mindful of the wealth of critical work on the proletariat I have limited my discussion of the literature to this one essay by Balibar (1994), for it is immediately useful in my specific concern to explore Marx's proletariat, through the framework of Deleuze and Guattari's minor politics, as an unnamable.

14 See Thoburn (2001) for discussion of some of the problems that arise in Negri's subjectivist interpretation of the proletariat.

15 Marx clearly makes this point when he writes: 'The sphere of circulation or commodity exchange, within whose boundaries the sale and purchase of labour-power goes on, is in fact a very Eden of the innate rights of man. It is the exclusive realm of Freedom, Equality, Property and Bentham' (1976: 280, emphasis added).

16 In the 'Critique of the Gotha Programme', Marx writes that a general prohibition of child labour ' - if possible - would be a reactionary step. ... [T] he early combination of productive labour with education is one of the most powerful means for the transformation of present society' (1974: 358).

17 It is noteworthy that from 1937 Soviet workers were no longer officially defined as a 'proletariat' (Gould and Kolb 1964: 547). The difference between the empirical reality of Soviet workers' lives (cf. Haraszti 1977) and their conceptual definition (as a proletariat so much 'for itself' that it had self-dissolved in the end of pre-history) hardly needs pointing out.

18 It should be noted that Marx (1973a: 240) draws a distinction between the 'conservative' smallholding peasant who seeks to consolidate this state of affairs and the 'revolutionary' peasant who, 'in alliance with the towns', 'strikes out beyond it'.

19 Marx famously describes the capital/labour relation thus: 'Capital is dead labour which, vampire-like, lives only by sucking living labour, and lives the more, the more labour it sucks' (1976: 342). Hence, in stark comparison to the passage about child labour above, Marx writes: 'Factory work exhausts the nervous system to the uttermost; at the same time, it does away with the many-sided play of the muscles, and confiscates every atom of freedom, both in bodily and in intellectual activity' (1976: 548). See Marx (1973b: 123) for a clear statement that this is nothing peculiar to 'factory' work, and Midnight Notes (1981: 1) for a more recent version of this position.

20 For this reason Gilles Dauvé argues that 'All theories (either bourgeois, fascist, stalinist, left-wing or "gauchistes") which in any way glorify and praise the proletariat as it is and claim for it the positive role of defending values and regenerating society, are counter-revolutionary. Worship of the proletariat has become one of the most efficient and dangerous weapons of capital' (1997: 30).

21 This point is most succinctly made by Mario Tronti: 'To struggle against capital, the working class must fight against itself insofar as it is capital' (cited in Deleuze and Guattari 1988: 571).

22 At a more empirical level, the way that the critique of work straddles both lumpenproletarian and proletarian formations leaves Marx in a much more sticky position than I am able, in this conceptual elaboration, to explore here. A brief point, however, can be made. By placing the transatlantic relations and flows of people, ideas and practices at the centre of analysis, Linebaugh (1991), Linebaugh and Rediker (1990) and Gilroy (1993) have shown how a complex, vibrant, multi-racial, transatlantic working class existed long before Marx and Engels were placing their hopes, in the Manifesto for example, in the 
workers of the relatively territorially and culturally fixed factory. If we are to follow this argument, a number of the peoples and social sites Marx was inclined to see as manifesting lumpenproletarian tendencies - the 'escaped galley slaves' and the taverns of the docks, for example - can be seen as traversed by capitalist social relations. As such, the critique of work that emerges among these peoples can actually be seen as a product of proletarian experience. Research in this direction does not undermine Marx's conceptual elaboration of the proletariat, but it can help to overcome some of the more narrowly focused, moralistic and, at times, racist aspects (cf. Ritter 1976) of his and Engels' more empirical work on lumpen and proletarian formations. It can also provide a rich site for the exploration of the techniques, styles, knowledges and inventions of historical proletarian politics. Linebaugh and Rediker (1990: 240), for example, have shown that the 'strike' was an invention not of the factory, but of the ship (as a practice of 'striking' the ropes of the ship's sails to prevent it from sailing).

23 Here 'working class' is meant in its sociological sense as an empirical group of people, a group identity.

24 Marx does, of course, produce outlines of possible practice and sets of demands (in, for example, the Manifesto or the programme of the International), but none of these are anything but situated in time and space.

25 It is in these terms that Deleuze describes his and Guattari's Marxism: 'I think Félix Guattari and I have remained Marxists, in our two different ways, perhaps, but both of us. You see, we think any political philosophy must turn on the analysis of capitalism and the way it has developed' (1995: 171).

26 It is important to note that, for Deleuze and Guattari, this dispersion of points of political tension and invention is not an assertion of minority independence. Minority inventions tend towards proletarian composition only insofar as their concerns and inventions are articulated and reverberate in a fashion that prevents an isolated 'solution'. Deleuze thus provocatively calls for a certain 'centralization': 'It is obvious that a revolutionary machine cannot content itself with local, punctual struggles: hyper-desiring and hyper-centralized, it must be all of that at once' (1977: 104-5).

27 An example (though one that itself should not be fetishized) can suffice for illustration. This understanding of the proletariat as a compulsion to the analysis and elaboration of specific and contemporary forms of work and its critique can be seen as the basis for the practical and theoretical invention of the Italian operaismo and autonomia movements of the 1960s and 1970s. Rather than become fixated on a particular proletarian form (say, the mass worker of Fordism), these movements' understanding of 'class composition' encouraged a focus on new and changing forms of socialized, diffuse and later - immaterial and affective work, new technological paradigms, and the changing political tactics, cultures, demands and styles of workers' politics - including base committees outside the unions, wildcat strikes, sabotage, struggles linking the workplace with the wider community, the school, the university, and the condition of unemployment, feminist struggle for wages for housework, autonomous price setting and selfreduction of utility bills, and counter-cultural practices of squatting, pirate radio and experiments with linguistic form (cf. Semiotext(e) 1980).

\section{References}

Ansell Pearson, K. (1997) Viroid Life:

Perspectives on Nietzsche and the

Transhuman Condition, London:

Routledge.

Avrich, P. (1987) Bakunin and Nechaev, London: Freedom Press.

Bakunin, M. (n.d.) Bakunin on Violence:
Letter to S. Nechayev fune 21870 , New

York: Anarchist Switchboard. (1973) Bakunin on Anarchy: Selected Works by the Activist-Founder of World Anarchism, trans. and ed. S. Dolgoff, London: Allen \& Unwin.

Balibar, E. (1988) 'The notion of class 
politics in Marx', trans. D. Parent-Ruccio and F. R. Annunziato, Rethinking Marxism 1(2): 18-51.

_- (1994) 'In search of the proletariat', in Masses, Classes, Ideas: Studies on Politics and Philosophy before and after Marx, trans. J. Swenson, London: Routledge.

Beckett, S. (1979) The Beckett Trilogy: Molloy, Malone Dies, The Unnamable, trans. S. Beckett and P. Bowles, London: Picador.

Benjamin, W. (1983) Charles Baudelaire: A Lyric Poet in the Era of High Capitalism, trans. H. Zohn, London: Verso.

Bestor, A. E. (1948) 'The evolution of the socialist vocabulary', Fournal of the

History of Ideas 9(3): 259-302.

Blissett, L. and Home, S. (n.d.) Green Apocalypse, London: Unpopular Books.

Bovenkerk, F. (1984) 'The rehabilitation of the rabble; how and why Marx and Engels wrongly depicted the lumpenproletariat as a reactionary force', Netherlands Journal of Sociology 20(1): 13-41.

Briefs, G. A. (1937) The Proletariat: A Challenge to Western Civilization, London: McGraw-Hill.

Camatte, J. (1995) 'On organisation', in A. Trotter (ed.), This World We Must Leave and Other Essays, New York:

Autonomedia.

Chevalier, L. (1973) Labouring Classes and Dangerous Classes in Paris during the First Half of the Nineteenth Century, trans. F. Jellinek, London: RKP.

Cleaver, E. (1970) On the Ideology of the Black Panther Party (Part 1), San Francisco: Black Panther Party. Dauvé, G. (1997) 'Capitalism and communism', in G. Dauvé and F. Martin, The Eclipse and Re-Emergence of the Communist Movement, revised edn, London: Antagonism Press.

Debord, G. (1983) Society of the Spectacle, Detroit: Black \& Red. Debray, R. (1995) 'Remarks on the spectacle', trans. E. Rauth, New Left Reviem 214: 134-41.

Deleuze, G. (1977) 'Three group problems', trans. M. Seem, Semiotext (e): Anti-Oedipus 2(3): 99-109.
(1989) Cinema 2: The Time-Image, trans. H. Tomlinson and R. Galeta, London: Athlone.

__ (1994) Difference and Repetition, trans. P. Patton, New York: Columbia University Press.

__ (1995) Negotiations: 1972-1990, trans. M. Joughin, New York: Columbia University Press.

__ and Guattari, F. (1983) Anti-

Oedipus: Capitalism and Schizophrenia, Vol. 1, trans. R. Hurley, M. Seem and H.

L. Lane, London: Athlone. and — (1986) Kafka: Tomards a

Minor Literature, trans. D. Polan, London: Minnesota University Press. —_ and _- (1988) A Thousand

Plateaus: Capitalism and Schizophrenia, Vol. 2, trans. B. Massumi, London: Athlone.

Derrida, J. (1994) Spectres of Marx: The State of the Debt, the Work of Mourning, and the Nem International, trans.

P. Kamuf, London: Routledge.

Donzelot, J. (1979) 'The poverty of political culture', trans. C. Venn, Ideology and Consciousness 5: 73-86.

Draper, H. (1972) 'The concept of the "lumpenproletariat" in Marx and Engels', Economie et Sociétés 2285-312.

Fanon, F. (1967) The Wretched of the Earth, trans. C. Farrington, London: Penguin.

Foucault, M. (1977) 'Nietzsche, genealogy, history', in Language, CounterMemory, Practice: Selected Essays and Interviems, trans. D. F. Bouchard and S. Simon, Ithaca, NY: Cornell University Press.

Gilroy, P. (1993) The Black Atlantic: Modernity and Double Consciousness, London: Verso. and Simm, J. (1985) 'Law, order and the state of the Left', Capital and Class 25: 15-55.

Gould, J. and Kolb, W. L. (eds) (1964) $A$ Dictionary of the Social Sciences, London: Tavistock.

Hall, S., Crither, C., Jefferson, T., Clarke, J. and Roberts, B. (1978) Policing the Crisis: Mugging, the State, and Law and Order, London: Macmillan. 
Haraszti, M. (1977) $A$ Worker in a Worker's State: Piece-Rates in Hungary, trans. M. Wright, Harmondsworth: Penguin.

Hirst, P. Q. (1972) 'Marx and Engels on law, crime and morality', Economy and Society 1(1): 28-56.

Kafka, F. (1972) The Diaries of Franz Kafka, 1910-23, ed. M. Brod, trans. J. Kresh and M. Greenberg, London: Penguin.

Linebaugh, P. (1991) The London Hanged: Crime and Civil Society in the Eighteenth Century, London: Penguin. _ and Rediker, M. (1990) 'The manyheaded hydra: sailors, slaves, and the Atlantic working class in the eighteenth century', Journal of Historical Sociology 3(3): 225-52.

Marx, K. (1973a) 'The Eighteenth Brumaire of Louis Bonaparte', in Surveys from Exile, trans. P. Jackson, Harmondsworth: Penguin.

(1973b) Grundrisse: Foundations of the Critique of Political Economy (Rough Draft), trans. M. Nicolaus, Harmondsworth: Penguin. (1973c) 'The class struggles in France: 1848 to 1850 ', in Surveys from Exile, trans. P. Jackson, Harmondsworth: Penguin.

- (1974) 'Critique of the Gotha

Programme', trans. J. de Bres, in

D. Fernbach (ed.), The First International and After, Harmondsworth: Penguin.

(1975) 'A contribution to the critique of Hegel's philosophy of right. Introduction', in Early Writings, trans. R. Livingstone and $\mathrm{G}$. Benton,

Harmondsworth: Penguin.

(1976) Capital: A Critical Analysis of

Capitalist Production, Vol. 1, trans. B.

Fowkes, London: Penguin. (1978) The Eighteenth Brumaire of

Louis Bonaparte, Beijing: Foreign

Languages Press.

_ and Engels, F. (1973) Manifesto of the Communist Party, Beijing: Foreign Languages Press.

$\longrightarrow$ and (1976) Collected Works Volume 5, 1845-47, London: Lawrence \& Wishart.

and (1978) Collected Works
Volume 10, 1849-51, London: Lawrence \& Wishart.

— and - (1988) 'The Alliance of

Socialist Democracy and the International Working Men's Association', in Collected Works Volume 23, 1871-74, London:

Lawrence \& Wishart.

- and (1995) Collected Works

Volume 47, 1883-86, London: Lawrence \& Wishart.

Mehlman, J. (1977) Revolution and Repetition: Marx/Hugo/Balzac, London: University of California Press.

Midnight Notes (1981) Space Notes 4. Nechayev, S. (1989) Catechism of the Revolutionist, trans. H. Sternberg and L. Bott, London: Violette Nozieres Press, Active Distribution and A. K. Press. Negri, A. (1991) Marx beyond Marx: Lessons on the Grundrisse, trans. H. Cleaver, M. Ryan and M. Viano, London: Pluto Press.

Nicolaevsky, B. (1997) The Revolution is Not a Masonic Affair: Boris Nicolaevsky's Study of 'Secret Societies in the First International', London: Unpopular Books.

Nietzsche, F. (1968) The Will to Power, ed. W. Kaufmann, trans. W. Kaufmann and R. J. Hollingdale, New York: Vintage Books.

Parker, A. (1993) 'Unthinking sex:

Marx, Engels, and the scene of writing', in M. Warner (ed.) Fear of a Queer Planet: Queer Politics and Social Theory, London: Minnesota University Press.

Ritter, H. R. (1976) 'Friedrich Engels and the East European nationality problem', East European Quarterly 10(2): 137-52.

Pyziur, E. (1968) The Doctrine of Anarchism of Michael A. Bakunin, Chicago: Gateway.

Semiotext(e) (1980) Italy: AutonomiaPost-Political Politics 3(3).

Spivak, G. C. (1996) The Spivak Reader, eds D. Landry and G. MacLean, London: Routledge.

Stallybrass, P. (1990) 'Marx and heterogeneity: thinking the lumpenproletariat', Representations 31: 69-95. 
and White, S. (1986) The Politics and Poetics of Transgression, London: Methuen.

Thoburn, N. (2001) 'Autonomous production? On Negri's "new synthesis", Theory, Culture ES Society 18(5): 75-96.
Traugott, M. (1980) 'The mobile guard in the French Revolution of 1848', Theory and Society 9: 683-720.

Wheen, F. (1999) Karl Marx, London: Fourth Estate.

Zerowork (1975) Political Materials 1. 
Copyright of Economy \& Society is the property of Routledge, Ltd. and its content may not be copied or emailed to multiple sites or posted to a listserv without the copyright holder's express written permission. However, users may print, download, or email articles for individual use. 